\title{
Responsible forms of project management education: theoretical plurality and reflective pedagogies
}

\author{
Svetlana Cicmil and Hugo Gaggiotti \\ Faculty of Business and Law \\ University of the West of England, Bristol \\ Frenchay Campus, Bristol BS 16 1UB \\ UK
}

\begin{abstract}
:
The paper aims to revive an interest in the notion of responsible project management education (RPME) in the context of related contemporary debates about: the integration of reflexivity, ethics and sustainability in business schools' curricula; the purpose, values and effectiveness of university education; and practical relevance of business and management courses, to mention only a few. We offer an interpretation of what RPME at university level may mean, concerning the practice of curriculum design and pedagogy of project management courses in light of a perceived nature of project management theory and the field as practised. We argue that responsible project management education should make the theorising of the process of projectification, relational complexity and practical wisdom (combining prudence, instrumental and value rationality) accessible and appealing to all involved and should pursue experiential reflective learning. To illustrate how it may work in practice, we reflect on our longstanding experience with designing and delivering a PM module for an MBA programme. Apart from the challenge with maintaining the requisite diversity of the teaching team and practitioners' input into the course, we illuminate some benefits and challenges as perceived by the participating students. These are: discomfort caused by encountering a different 'project management'; excitement in embracing the unexpected; light-bulb moments in redefining one's own understanding of PM practice and in finding a new way of understanding and dealing with a specific situation in the workplace.
\end{abstract}

Key words: responsible management education; innovative project management course design and pedagogy; applied theorising; interdisciplinary dialogue; reflection; MBA classroom 


\section{$\underline{1 . \text { Executive summary }}$}

There is a prevailing perception of Project Management (PM) as a universally applicable managerial discipline grounded in a set of tried and tested methods, tools and techniques for planning and controlling work for organised and efficient delivery of discrete undertakings defined as projects. In the paper, we take the issue with such a narrow view of projects and project management which has over many decades influenced the content of project management education. We question its adequacy in a complex, ambiguous and diverse global world by drawing on a wider contemporary debate around the values and purpose of management education at university level and its relevance to practice.

In the first part of the paper, we conceptualise and justify a set of pedagogic and theoretical principles of responsible project management education (RPME) centred around theoretical plurality and reflective experiential pedagogies. We argue that RPME requires focusing on the skills, knowledge and competencies of PM as well as on a diverse, political and ambiguous context of contemporary projects and projectified society. It should openly encourage reflection on ethics, accountability and the multiple values at play in PM practice. In RPME, the understanding of the projectification process, existential reflection on complexity and the development of an ability to exercise practical wisdom, are treated as equally important as the teaching of conventional PM models and techniques.

We then empirically explore the benefits of, and challenges with, integrating these principles into our practice as management educators. The analysis of a concrete PM course case, using our personal reflections and the students' feedback over a number of years, illuminates important issues regarding the effectiveness, benefits and challenges of our pedagogic practice. For example, Turner and Cochrane's (1993) project typology matrix in an adapted form can serve as an inspirational introductory framework for making contemporary theories and theorising of projectification, relational complexity and practical wisdom (combining instrumental and value rationality) accessible and appealing. Careful attention needs to be given to the composition of the teaching team to harness epistemological diversity. A reflective ethnographic form of assessment fosters an awareness of situational ethics and concrete reflective analyses of lived experience with projects, including the practice of theorising.

We argue for further research into the concept of RPME and its implementation in practice. Some important areas for attention are: a) students' perceptions of discomfort caused by encountering a different 'project management'; b) creative potential of their excitement in embracing the unexpected; 
and c) light-bulb moments in finding a new way of understanding and dealing with a specific situation in their workplace more generally.

\section{Introduction and rationale - the phantasy of an idealised Project Management mind-set in the context of ambiguous organising}

'Project management is no longer an organised and orderly game where the players pursue preconceived plans to achieve predetermined ends, but an ongoing play with chance and probability in an environment where not only players but also the rules of the game, are subject to change'. (Laszlo, 1994, p.3-5)

This statement challenges the very assumptions behind a global and ever-rising interest in projectbased organising and management since the 1980s - the assumptions which have made PM universally appealing as both a powerful, structured management methodology and a promising organising model for efficiently implementing strategic change, creative ideas and major development initiatives. The notions of 'playing with chance and probability' and 'changing rules of the game', used by Laszlo to describe a reality of PM practice, stand in stark contrast to standard methodologies which imply and promote an idealised, persuasive, command-and-control model of the PM process, driven by knowledgeable project managers with known and consistent preferences, with adequate information and clear organisational status (Buchanan and Boddy, 1992; Buchanan and Badham, 1999). While a messy, ambiguous, fragmented and political nature of contemporary organising within which projects are being managed has now been widely acknowledged, the universal PM best practice prescriptions and professional standards have continued to be promoted as critical to managing projects efficiently and, as such, remain at the core of most PM courses. These include a traditional range of, now ICT-modernised, project planning and control tools (Gantt, CPM, EVA, PERT) and acontextual governance models (PRINCE 2, Six Sigma, etc). The perception of these tools and techniques as being accessible, adaptable, scalable and thus universally effective seems to be at the heart of a rising tendency to routinely label work tasks as "projects" which, it is often assumed, increases the visibility and controllability of these tasks and the likelihood of their successful outcomes. This has, over recent decades, given rise to a project-driven and project-dependent economy, where newly minted projects (and, for that matter, related success criteria) no longer resemble the original definition and traditional contexts of project-based industries (aerospace, construction, defence) but emerge discursively (e.g. Lindgren and Packendorff, 2007; Lindahl and Rehn, 2007; Fincham, 2002).

As a result, a significant number of organisational members have been and are being redefined as project managers and project workers, needing relevant upskilling. Training courses in 'PM basics' 
have been offered even to school-age pupils, reinforcing a particular view of PM best practice across generations, sectors and societal groups, thus entrenching PM further into the rational-instrumental paradigm while, simultaneously and paradoxically, profiling it as mundane (titles such as 'PM Pocket Guide' or 'The Complete Idiot's Guide to Project Management' are not rare). It can be argued that, as a consequence, PM as an academic subject has remained rather closed to more imaginative, experimental philosophical and socio-political conceptualisations of the practice of project-based work. Until the turn of the century, PM was rarely researched, let alone taught, by general management and organisational studies scholars.

Scholarly interest in these and related issues since the late 1990s has resulted in a wide range of academic-practitioner partnerships, research initiatives (including those funded by PM professional bodies) and related volumes and journal special issues (see e.g. Walker and Lloyd-Walker, 2017, for an overview). This paper is specifically informed by the emerging and evolving strands of management studies that have illuminated the process of projectification of work-life and society (Maylor et al, 2006; Cicmil et al, 2016; Hodgson et al, 2016). The consequences of projectification for individual and professional identity (Smith, 2006; Paton and Hodgson, 2016; Rolfe et al, 2017), economic performance (Fincham, 2002; Lindahl and Rehn, 2007; Flyvbjerg, 2014) and international development (Lannon et al, 2016) are particularly significant. Similarly, research around the sociopolitical and ethical aspects of project-related decision-making and the colonising power of project discourse is revealing. Processual approaches in studying projects and PM have highlighted the significance of understanding complex processes of human relating in unpredictable, ambiguous global project-based environments (Stacey, 2016; Cooke-Davies et al, 2007; Linehan and Kavanagh, 2006; Clegg et al, 2006), and the possibilities of philosophical practice in the field of projects and PM (Konstantinou and Müller, 2016; Rolfe et al, 2017)).

We have intentionally chosen to start with a reference to Laszlo's work from the early 1990s, and to illuminate its contemporary significance. His was a pioneering call for 'responsible (project) management' (Laszlo, 1994, p.3-4) understood as 'sound evolutionary management' (ibid.) - a call to acknowledge the nature of PM practice as situated in an unpredictably evolving context of shifting currents in corporate strategies and paradoxical conditions of the dominant socio-political world order. As later argued by Flyvbjerg (2001), in order to be responsible, the development of project managers as skilful technicians and implementers of plans needs enhancing with the notion of practical wisdom, a virtue essential for action in an environment where multiple and competing values, agendas and expectations are at stake. We are unaware of any significant recent debate around the notion of responsible project management education: what it might mean in practice and how it 
should be shaped to reflect those imperatives. With this paper we wish to join scholarly conversations concerned with the purpose, nature, value, societal impact and effectiveness of PM courses at university business schools, and of university-based management education more broadly. We will argue that collective attention (of academics, training consultants, professional bodies, practitioners, students and university management) should be refocused on addressing the important question of responsibility and the ethical-practical relevance of PM education. Our intention is specifically influenced by some recent institutional and global imperatives, most significantly the calls for responsible management education, the integration of reflexivity, aesthetics, ethics and sustainability in business schools' curricula, research-informed teaching in business and management studies and an enhanced practical relevance of business and management courses (PRME 2017a, 2017b; Izak et al, 2017; Cicmil et al, 2017; Painter-Morland et al, 2016; Hibbert, 2013), to mention only a few. We use concrete examples from our own PM course syllabi, a large body of primary data in the form of our students' feedback and personal reflections of the members of the teaching team to illustrate, justify and open to the readers' scrutiny the theoretical propositions made in the paper.

\section{A view on responsible project management education}

“.... it can be dangerous for individuals, groups, and societies when their capacity for valuerational deliberations is eroded. Today the erosion of such capacity seems to many to be rapidly taking place and coincides with the growing incursion of a narrow means-rationality into social and political life." (Flyvbjerg, 2001, p.168)

The United Nations' initiative Global Compact, established in 2000, represents a community of business leaders concerned with the multiple crises the global society has faced since the turn of the millennia (PRME, 2017a). Since then, UN Global Compact has, in partnership with participating academic institutions, introduced and defined the principles of responsible management education (PRME) in this context. PRME encourage management education practices which actively and transparently address and continuously refine: clarity of purpose and values, effectiveness of the teaching methods used, relevance of research that underpins them; the quality and diversity of partnerships created with relevant groups; and the level of their participation in an open and critical dialogue (PRME, 2017b; Solitander et al, 2012; Painter-Morland, 2015). Elliott (2003) suggested that if accountability, practical relevance and responsibility of management education are to be usefully studied, then its pedagogy has to be a focus of such studies to an equal extent as its content. Holman's (2000) critical evaluation of the models of management education revealed the importance of paying attention to five interrelated dimensions (epistemic, pedagogical, management-as-practice, social, and organisational) in designing and delivering management courses at university level to enable the "complexity and non-mechanistic nature of managerial practice to be fully addressed" (Holman, 2000, 
p.209). Holman suggests two considerations as fundamental for developing managers better equipped to cope with the heterodoxies and liquid nature of the world in which their employment prospects are situated (Gaggiotti et al, 2017). One is ensuring epistemological plurality: i.e. the equal presence of objective and subjective epistemologies among management educators. The other is adopting alternative pedagogies and teaching practices which recognise on-the-job learning, reflection, critical thinking and "alternative forms of knowing" (Holman, 2000, p.210). Moreover, it has been argued that such approaches also encourage educators to reflect on their own practice and on the changing nature of academic work (e.g. Hibbert, 2013; Holman, 2000) and as such, must be recognised as an important factor in responsible management education.

One strand of research into the future of business schools and the purpose of management education at universities (Izak et al, 2017; Steyaert et al, 2016), is specifically concerned with the lack of theorising and contemplation of ethics in management education. Management education is seen as being increasingly driven by the logic of economic growth and graduate employability, with the possibility of a deeper ethical examination of management practices and the lived experience, as an aspect of education, gradually removed. The context of management education has become, according to some, an ideological terrain in which education is deemed as 'a socially valuable enterprise contributing to national economic prosperity, as well as a consumer good to be obtained by individuals to further their careers' (Elliott, 2003, p.415). Therefore, it is argued, considerations of alternative ways of understanding and imagining organisations and management have been sidelined as impractical and irrelevant (Gaggiotti et al, 2017). Moreover, the implications for the identity, intellectual integrity, freedom, and perceived or expected role of academic management educators are rarely addressed.

\subsection{Listening to students' voices}

For us, academics teaching PM, there is an important ethical pedagogical call to acknowledge and respond to the expectations of students on PM courses. In our experience, these expectations are often contradictory and resonate anxiety, dilemmas and bewilderment. The students are generally aware of complexities and ambiguities of project based work and management in their workplace. They speak about the confusion caused by a variety of work tasks being randomly or counterproductively called and managed as 'projects'. They mention the frustration with a lack of collaboration, ineffectiveness of PM 'tools' and complex relationships on multiple projects over a number of years. They are both inspired by and concerned about the possibilities of Project Management as a professional aspiration. However, the students seek logical explanations of those disruptions, largely expecting to learn 
concrete practical resolutions - effective PM tools as well as 'soft' skills and strategies for personal resilience - that are immediately applicable in practice. They insist that the balance be struck between the academic PM theory, their own voice as real-world practitioners and case study based discussions.

This poses a challenge for lecturers of PM-related modules who aspire to live up to the imperatives of 'relevance', applicability, employability and responsibility all at once. Some authors have introduced the classroom practices of 'relevating' (Paton et al, 2013), existential questioning (Rolfe et al, 2017) and a live case approach (Roth and Smith, 2009). These rely on theorising, understood as contemplation of other possible ways of imagining projects and PM practice, and reflective examination of distractions in one's own lived experience.

\subsection{Principles of responsible project management education - a proposition}

The aspiration towards (responsibly) educating responsible project decision-makers and managers is an important but challenging one. In Table 2 we summarize the discussion from the preceding sections of the paper and propose a set of principles of responsible project management education (RPME) to be acknowledged and accommodated in practice. Clearly, a vision of RPME requires that attention be given to the complex relationship between pedagogy and course content. In the next section, we share with the reader our joint, decade long experience with the design and delivery of a module at MBA level in pursuit of the four RPME principles and inspired by Read and Anthony's (1992) assertion that 'education, even for management, must ultimately be a matter of faith, or belief in values that are fundamental' (p.607). This paper is itself reflective, as we simultaneously evaluate, justify and deliberate about our own practice as management educators with an eclectic range of personal research interests and positions on management knowledge and practice, and with unorthodox international careers spanning academia and industry. 
Table 14 Proposed Principles of Responsible Management Education in the context of a broader debate

\begin{tabular}{|c|c|c|}
\hline $\begin{array}{l}\text { Wurrent debates on management } \\
\text { ducation at university level (Section } \\
\text { ) }\end{array}$ & $\begin{array}{l}\text { The nature of } \\
\text { noM } \\
\text { nowledge system and } \\
\text { he field as practised } \\
\text { Section 2) }\end{array}$ & $\begin{array}{l}\text { rinciples of Responsible Project } \\
\text { Ianagement Education (RPME) }\end{array}$ \\
\hline $\begin{array}{l}\text { Research about purpose, value and } \\
\text { relevance of management education } \\
\text { calls for: } \\
\text { Epistemic plurality in management } \\
\text { education courses to enable } \\
\text { complexity and non-mechanistic, } \\
\text { embedded and embodied nature of } \\
\text { managerial practice to be fully } \\
\text { addressed. } \\
\text { Alternative pedagogies and } \\
\text { teaching practices which recognise } \\
\text { on-the-job learning, reflection, } \\
\text { critical thinking and "alternative } \\
\text { forms of knowing". } \\
>\text { Theorising as an aspect of } \\
\text { management education, deeper } \\
\text { ethical examination of the lived } \\
\text { experience of management. } \\
\text { Considerations of alternative ways } \\
\text { of understanding and imagining } \\
\text { organisations and management. } \\
\text { Educators to reflect on their own } \\
\text { practice and the role of the identity, } \\
\text { intellectual integrity and freedom. }\end{array}$ & $\begin{array}{l}\text { Universal PM best } \\
\text { practices, } \\
\text { methodologies and } \\
\text { professional PM } \\
\text { standards largely } \\
\text { underpin PM training. } \\
\text { Rational-instrumental } \\
\text { paradigm is dominant, } \\
\text { resulting in two } \\
\text { extremes: a highly } \\
\text { techno-scientific basis } \\
\text { of PM knowledge on } \\
\text { the one hand and a set } \\
\text { of basic universal PM } \\
\text { tools on the other. } \\
>\text { PM is a popular and } \\
\text { exponentially rising } \\
\text { profession / job. } \\
\text { The organisational } \\
\text { context of projects is } \\
\text { messy, ambiguous, } \\
\text { fragmented, culturally } \\
\text { diverse and political } \\
\text { Project-related } \\
\text { decision-making has } \\
\text { significant socio- } \\
\text { political and ethical } \\
\text { implications. }\end{array}$ & $\begin{array}{l}\text { 1. Introduce theoretical plurality_by } \\
\text { promoting a wider, research- } \\
\text { informed reading to expose the } \\
\text { fragmented nature of the PM field } \\
\text { and a range of often competing } \\
\text { models, theories, methods and } \\
\text { arguments. Legitimise and encourage } \\
\text { critique of the very object of the } \\
\text { study (project and PM) and its } \\
\text { discursive nature. } \\
\text { 2. Encourage a critical debate of } \\
\text { accountabilities, challenges and } \\
\text { anxieties associated with acting in an } \\
\text { economically sound, environmentally } \\
\text { friendly and socially responsible way } \\
\text { in complex project environments. } \\
\text { 3. Curriculum should be informed, } \\
\text { developed and delivered through } \\
\text { partnerships and dialogue with } \\
\text { practitioners, students, academic } \\
\text { researchers and professional bodies; } \\
\text { cultural sensitivity needed in } \\
\text { discussing their contextualised } \\
\text { experiences with projects and PM } \\
\text { and unavoidable interests/agendas at } \\
\text { play. } \\
\text { 4. Assessment forms which foster } \\
\text { theorising, involving knowledge } \\
\text { creation through reflection on the } \\
\text { lived experience and awareness of } \\
\text { situational ethics in a concrete } \\
\text { project context. }\end{array}$ \\
\hline
\end{tabular}

\section{4. 'Project Management in a Complex World': wider theorising and pedagogic experimentation in the delivery of an $\mathrm{MBA}$ module}

Project Management in a Complex World is a module within an MBA programme in a British business school, which is part of a post-1992 university. The programme is characterised by a high level of professional and cultural diversity with women now making up close to $40 \%$ of some cohorts. This module is delivered mainly in a block of 5 consecutive days to a mixed group of part- and full- 
time MBA students as their elective option. They have at least 3 years of prior organisational experience, which enables them to meet the key prerequisite of this elective, i.e. making links between their own experiences or understandings of PM and the key readings introduced in lectures. The module has been, under its current and previous (Project Management Executive) names, a popular MBA elective since 1998. Equally interestingly, it has inspired, over the last 10 years, consistently rich and constructively critical participants' feedback for its unorthodox content:

A very thought provoking module. ... the style allowed me to think about projects I had been involved in from many perspectives and in fact offered some light-bulb moments. Had we only stuck to one of the usual project management methods I would not have thought about some of the projects in the context I did. $\{$ course participant A-2016\}

and also for its innovative pedagogical approach:

I have an engineering background so this was completely different for me. I've never experienced project management on the scale the tutors were talking about. ... I'm still thinking about it! (a course observer, prospective MBA candidate)

Indeed, the distinctiveness of this module, driven by its commitment to the principles of responsible education, is threefold, as outlined, with examples and references, in Figure 1. As for its pedagogic approach, the module has been firmly grounded in reflective pedagogy (Brockbank and McGill, 2007), a student-centred methodology by which students learn through a process of reflecting and engaging with constructs of Project Management embedded in their organisational experiences and in academic texts. The second distinctive characteristic is in its attention to the controversies within the field discussed in the introductory section of this paper. The syllabus is open to a wide range of theoretical and ethical concepts relevant to PM as experienced in practice, centring around the concepts of complexity, projectification and practical wisdom. Last, but not least, a distinctive point of the module is its assessment format, which gives the students an opportunity to individually and deeply reflect on their learning, on its relevance to their practice and professional aspirations, and on ethical aspects of both PM practice and PM knowledge. We now elaborate on each in turn. 
The project typology / goals and methods matrix (Turner and Cochrane, 1993) as an inspiration and a call to reconsider the pervasive conventional Project Management wisdom:

- Can 'project' be objectively and universally defined? What is a project?

- Inevitable uncertainty and ambiguity of project goals

- Social and relational dynamics in organising and accomplishing project work

- The resulting contingent nature of project planning and control and of project success/failure

- Project management practice in project-based settings - skills, knowledge and lived experience

\section{Complexity thinking, e.g.}

- project work and management understood processually; as outcomes of conversational, symbolic and power relating among project participants

- the nature of these processes of human relating are unpredictable (unplannable), emergent and evolving in the specific context

- management action and control as navigation of collective meaning-making through participation in these processes

As argued by: Stacey, 2016; Cicmil et al, 2006; Linehan and Kavanagh, 2006

\section{Projectification, e.g.;}

social and discursive construction of project and PM

- widespread labelling of work tasks as projects

- identity implications of proliferation of project workers and managers

As argued by: Maylor et al, 2006; Cicmil et al, 2016; Fowler et al, 2015

\section{Practical wisdom}

- social and political virtuosity

- value rationality above and

beyond instrumental knowledge

of tools and techniques;

- existential questioning of lived experience;

Indicative references: Van Der Hoorn and Whitty, 2015; Cicmil, 2006; Flyvbjerg, 2001

The key themes of the module - nature of work labeled 'project'; project control and success/failure dilemma; project based organising; governance of multiple projects; ethics of project collaboration; work-life balance; accountable decision-making under uncertainty; PM Profession and professional workers on projects; cultural diversity, identity, existential dilemmas and professional conduct;

Pedagogic approach for responsible PM education: reimagining projects and project management to make lived experience accessible for examination; making the familiar unfamiliar through theorising; critically evaluating conventional wisdom of and dominant theories about, P\&PM; participatory practical knowledge creation in the classroom embracing a number of PM logics: control, process, legitimacy and ownership (Buchanan and Badham, 1999); experiential learning; has to be liberating (Freire, 2013 [1974])

Assessment: a thick-description based reflective ethnographic essay on personal experience encouraging reconnection with embodied lived

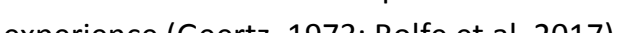

Figure 1. An overview of the content and pedagogy of a module reflecting the principles of RPME 
4.1 'Typology matrix' as a tool for making theories and theorising accessible and appealing

Over the years, we found the original 'goals and methods matrix' (Turner and Cochrane, 1993; Turner, 1995) and the resulting project typology (re-presented in Figure 2) useful as an inspirational introductory teaching framework for a) making the subject area theoretically appealing to students on the MBA programme; b) making relevant theories and the process of theorising accessible in the classroom, and c) enhancing the students' ability to reimagine PM practice and reflect on their own experience in action. Turner and Cochrane's (1993) analysis of the nature and level of ambiguity of the project's goals and applicable PM methods over project life cycle suggested a set of adequate start-up, team-building and implementation strategies and techniques for each of the 4 indicative types of projects in the matrix. The authors also acknowledged the inherent technical, political and social challenges of each project type, requiring non-traditional and flexible approaches to organising project participants and managing their co-operative input to produce the expected, beneficial deliverable. Some non-standard, contingent PM methods such as rolling-wave planning, configuration management and prolonged negotiation of requirements and benefits among the key project stakeholders 'right up to the completion of the project as new information becomes available about what will be beneficial or worthwhile' (Turner and Cochrane, 1993, p.94) were suggested as appropriate for certain types of projects.

Type 2 -water

No

(Product development projects)
Multi-disciplinary teams
Brainstorm
Participative emergent PM
techniques
PM: coach

Methods can be defined and agreed early
Type 1 earth

(engineering projects) specialist implementers Traditional PM techniques close coordination of multidisciplinary work PM: conductor Yes

\author{
Type 4 - air \\ (org.change projects) \\ Inspiration, creativity, negotiation \\ strategy definition \\ communication as processes of \\ power relating; symbolic interaction \\ and conversations \\ PM: eagle
}

Yes

No

Goals/Objectives can be understood and agreed early

Figure 2. Re-presenting the original project typology matrix and respective project management priorities. Adapted from Turner and Cochrane (1993). 
This can inspire collective reflection in the class on complex dynamics among interests, agendas, performance expectations and behaviours of project parties involved in both governing and accomplishing project work. Each project type suggested by the matrix embodies a different nature and level of unpredictability, ambiguity, emergence, micro-diversity and paradox, hence requiring a deeper examination of what is meant by successful project management practice in such complex socio-technical collaborative arrangements labelled 'project'. The typology, therefore, offers a potential for accommodating theoretical concepts of complexity (more specifically, the studies of relational complexity in organisations), practical wisdom and projectification (Figure 1). Practical theoretical imagination and reflection involved in assessing levels of complexity and vulnerability of a project at hand (Figure 2) focus the learner's attention on:

1. a variety of undertakings being labelled, set up and /or managed as 'project' which do not necessarily lend themselves to traditional PM methodologies;

2. the meaning of project success, where 'the project is only successful if it produces a worthwhile product which can be operated beneficially for some time after the completion of the project to repay the investment in it' (Turner and Cochrane, 1993, p.94) while that which is worthwhile and beneficial cannot always be known in advance so planning and control has to be participatory and project risks understood in those terms;

3. complex interpersonal dynamics, multiple agendas and other challenges to team-work coordination and multi-disciplinary collaboration;

4. reimagining the nature of project manager's competencies, experience and knowledge needed to deliver different types of projects successfully, introducing metaphors for related PM action, i.e. eagle, sculptor, coach, and conductor.

Developing a critical awareness of the context and history-dependent relational complexity of all projects and of practical wisdom (capacity for reflection and action) contributes to the student's capacity to lead in the global and increasingly virtual project-based environments. Our educational emphasis is particularly on the evolving collaborative action in accomplishing project work, which is conditioned by the participants' individual and shared sense of identity, fear, freedom, security and power, and their firmly held values, sense of justice and ethics, all of which they consciously and unconsciously bring into their work and permanently negotiate with others. Through theorising and reflection, we aim to develop students' understanding that

- the project manager him/her-self is also a participant in these complex relational processes rather than an objective observer standing outside of the collaborative action, attempting to direct it in a desired direction of a predetermined goal;

- control and coordination of project work has qualities of persuasive social and political action; the managers' conversational virtuosity and facilitation of shared meaning among the involved project members or other stakeholders are critical in inducing cooperation which results in a desired outcome 
- the 'control process' can therefore be reimagined as a collaboration-building process based on a shared sense of benefit and gain amid multiple expectations, agendas and interpretations of the purpose of the project at hand;

- responsible PM development is no longer solely about improving tools, techniques, models and frameworks for controlled delivery of project goals that are ambiguous and never fully known in advance of them happening but, equally, about mastering the required social and political virtuosity.

\subsection{Our pedagogic approach}

Pursuing a deeper theoretical discussion of the project typology matrix in the classroom, with the aim of inspiring a constructive debate around alternative possibilities for practical action in project settings, is not straightforward. The pedagogic approach needs to be carefully designed to maintain, rather than inhibit, intellectual curiosity, by balancing the attention given to instrumental rationality (tools, techniques and standards) with the concept of situated practical wisdom (social and political virtuosity and ethical reflexivity in applying those tools). One of our main tasks over the many years of delivering the module has indeed been to find ways of responsibly 'relevating' (Paton et al, 2013), i.e. making a seemingly irrelevant over-theorisation accessible and liberating to our MBA students in their everyday practice. Practitioner guest speakers, many of whom are our former students, are invited to actively reflect on the deliberative themes of the module (outlined in Figure 1) and, where applicable, comment on the impact of our pedagogic strategies on their practical coping in project environments and on their career progression and successes.

Our pedagogy draws on the concept of critical consciousness (Freire, 2013 [1974]) encouraging cultural sensitivity in the dialogue among students, lecturers, and guest speakers. We start with classroom-based considerations of the concepts of complexity, projectification, and the historical and human condition of concrete project situations. Alongside reflections on personal lived experience with projects and PM and study-visits to live 'projects' and project based organisations, the pedagogic process often results in the students' facing the familiar in an unfamiliar way. The following testimony, chosen from the most recent feedback set, illustrates an insightful thought on our MBA students' engagement:

This is a complex module that I feel could only be delivered by a team with both an academic foundation and a vast knowledge of the subject matter from practical experience. This combination allowed questions and opposing opinions to be discussed with full recognition that the 'real' world did not always match the academic management literature. Something which I have seen lecturers with limited practical experience struggle with. \{Course participant B-2016\} 
We have ensured and maintained as a requisite the multi-disciplinarity and cultural diversity of the teaching team. It has been formed largely spontaneously over time, through our shared research interests in the pervasiveness of project-based work and paradoxical implications of contemporary projects on individuals (e.g. professionalization, accidental project managers) and on society (e.g. controversial performance of major projects and ambiguity of their success or failure). The core teaching team consists of four academics with diverse scholarly backgrounds combining social psychology, organisational anthropology and ethnography, critical management studies, and economics, and an industry practitioner as a visiting lecturer with concrete PM expertise and experience. We nurture our collective ability to 'mediate' multiple and conflicting positions on PM in both literature and classroom discussions and in relation to various types of 'knowledges' promoted by academics, professional bodies and consultants.

\subsection{The assessment format}

The assessment for this module takes the form of a report resulting from an evaluation of a significant relevant personal experience. Students are required to produce not only an account of their detailed observations of a project/PM practice in their workplace, paying particular attention to the social context, but also of their own meaning-making process, with explicit references to how they perceived action, relationships, cultural differences, similarities and social patterns. This is based on Geertz's (1973) 'thick-description', introduced as a methodological inspiration. This method was developed by the anthropologist Clifford Geertz in what is considered his most influential work (The Interpretation of Cultures, 1973) with the intention of precisely helping the multiple meanings of observable social practices to become visible. Thick description in the context of our RPME aspirations is an invitation to describe, but more importantly, to self-reflect, reimagine and theorise on own circumstances, the context and the particularities of engaging in projects. It constitutes a way of writing and reflecting that helps to focus on micro details and social miniatures that are usually ignored by traditional qualitative or quantitative approaches, uncovering the multiple and usually contradictory ways in which projects come into being and unfold.

\section{On reflection: practical and ethical challenges of the approach}

In this section, we will discuss some challenges with designing and delivering a PM module at an MBA level which resonates with the principles of RPME. Both the MBA programme and the module have received, over a prolonged period of time, positive student feedback precisely because of its alternative, non-mainstream nature; for example: 
A very thought provoking module. ... the style allowed me to think about projects I had been involved in from many perspectives and in fact offered some light bulb moments \{course participant A-2016\}

In the preceding sections, we argued the rationale behind our experiments with the content and pedagogy of the module. It is now opportune to pause and reflect on the most recent post-completion feedback from the course participants to bring to light the contingent and complex nature of PM education and the fine balance between keeping the syllabus professionally attractive while attempting to enhance it with advanced, research informed, practical study of projects and project based work. The students' comments relate to three main issues: The unexpected; Participation and perceived practical relevance of the module content, and Discomfort, anxiety and unfulfilled expectations.

\subsection{The unexpected}

The themes and concepts addressed in the module (Figure 1) are contemplative, which means that there is neither a final, single answer, nor a concrete proven theory to apply; only continuous participative deliberations of complexity combined with reflection on action in concrete project situations. We argue that introducing theoretical plurality (RPME Principle 1, Table 1), an approach that emphasizes theorising instead of the application of theories (Gaggiotti et al, 2017), is necessary if PM education is to be responsible and relevant. Theorising can be liberating, as individual participants start to form an alternative understanding of the experience with project work and to reimagine PM practice in a way which enables, rather than restricts, action. Students testified that they felt enlightened:

Different concepts introduced to us were eye-opening as before this module I had no idea about the four type of projects and expectations related to them. \{course participant C-2016\}

realising that PM is not necessarily 'mundane' :

Really challenged my perception of project management. Prior to the module I had anticipated the module running through PM tools such as PRINCE2 and APM. I found the course material very refreshing, and really made me think about project overload in my current role. \{course participant A$2016\}$

and, equally importantly, experiencing light-bulb moments (gaining new insights, new understandings):

Educative and motivated self-reflection, with an open view to various options of viewing projects in a complex world. Exactly what I expect from an MBA course. \{course participant B-2016\}

\subsection{Participation and perceived practical relevance of the module content}


The pedagogy which relies on partnering and dialogue between the students, practitioner guest speakers and academic teaching team seems to encourage the learners' feelings of participation in the process of knowledge creation. In such a process, everyone in the classroom is always considered a credible knower of PM. Students' ability to critically and ethically evaluate credibility of extant sources of PM knowledge is developed in various ways. For example, with reference to the literature:

I like the large reference list as this gave me chance [sic.] to explore some of the papers and concepts. They were very relevant and gave me good guidance \{course participant B-2016\}

to the real-life cases presented by guess speakers:

Very practical as the project managers from reputable organisations were invited to give their professional and hands-on experience on project matters as the lecture unfolds. \{Course participant F$2016\}$

and to professional practices and expectations in their own organisations:

The projectification and the project overload topics helped me to analyse my current situation and the potential strategies to approach those issues will surely help me in improving my situation \{course participant $\mathrm{H}-2016\}$

The effectiveness of 'relevating' (Paton et al, 2013) efforts of the teaching team presents a huge challenge. We have had to constantly justify, illustrate, make appealing and accessible the chosen philosophical and theoretical concepts and readings, and to confidently encourage quiet contemplation of those, including out-of-classroom visits to project sites and situated dialogue in concrete locations. Students vocally expressed their perceptions of our efforts to live up to RPME:

The group were encouraged to ask questions, challenge and debate issues throughout the module and to bring their own work experiences into play too. \{Course participant I-2016\}

We were lucky to have an excellent cohort and a passionate teaching team from different backgrounds to contribute with their own experiences. \{Course participant J-2016\}

All the lecturers brought their personal research insight and used their personalities in the interest of the students. \{course participant G-2016\}

\subsection{Discomfort, anxiety and unfulfilled expectations}

However, it is also important to acknowledge the unsettling openness of this approach (for both students and lecturers). Deliberative theorising and participative pedagogies often result not in a discovery of a best management practice nor in definite answers to the initial questions, but in new definitions, new ethical concerns, new understandings and possibilities for context dependent action. The implications of such variability and indeterminism for our students have been stimulating but at the same time [at times?] uncomfortable, inhibiting and ineffective, thus potentially compromising the 
aims of RPME. Students emphasized their preference for concrete examples of what ultimately works and what does not:

I need clearer examples of successful / failed projects with reasons from multiple dimensions. What makes a perfect project? \{course participant M-2016\}

demanded more theoretical certainty:

I wanted to understand the principles behind some of the project management theories and practice e.g. PRINCE2 and to examine in what situations some of these frameworks work, where they don't and what differences are there between each type of framework. That would have helped me in particular where I engage with project managers and in some instances tend to disagree with the level of paperwork needed to manage all projects. \{course participant L-2016\}

and even concrete practical applicability:

Very good academic topic and in-depth research explored but more time should have been devoted for showing relevant practical tools for planning etc. \{course participant D-2016\}

From our experience over the years, the majority of MBA students opting to attend our PM elective come with a preconception that academic theorizing of projects and PM is irrelevant. They confuse the 'applied' and 'practically relevant' with the familiar, logical and technical (predictable) due to a relentless promotion of certain project management methodologies, techniques and tools, and an increasing appeal of PM professional certifications. The frustration is sometimes expressed in a form that resonates consumer dissatisfaction:

I'm not 100\% sure, but the module was not what I expected? It did not deal with the tools and techniques of PM, but concentrated on why the current PM models may not always be effective and on the shortcomings of the PM industry. I thought we needed to know the tools before we could know where their weaknesses where. \{course participant K-2016\}

Indeed, students have been initially uneasy with diverting attention away from the popular PM tools and methods, promoted in the workplace and assumed as 'given' (i.e. professional PM knowledge proper), expecting those to be easy to use once the appropriate skills and technical training are acquired during the module. With an imperative of employability as a measure of university education effectiveness, certification-driven knowledge is in demand, as are recognised professional PM qualifications.

Would there be an option for the University to utilise the module to provide students with a project management qualification that many employers are looking for alongside the style of this teaching that demonstrates that there is no 'one way' [sic] \{course participant J-2016\}

The feedback shows that we, management scholars, need to keep engaging with and debating the questions posed at the start of the paper: what is the purpose of PM education at university level and how to responsibly educate responsible project managers? It is obvious that the class dynamic is 
influenced by the widespread PM discourse promoting and favouring tools- and techniques- based PM knowledge and by the professionalisation of project managers as skilful, rational technicians capable of a heroic delivery of projects. As illustrated by our students' feedback, a challenge lies in reconciling and balancing the professional discourse with alternative possibilities and reflective theorising of lived experience in practice. This requires an allocation of appropriate time to the alternative topics and an attention to the order in which they are presented. We use the dialogue and learning partnership processes in the classroom, as explained earlier, to encourage an understanding of project managers' action in practice as a combination of public performance and backstage activity (Buchanan and Boddy, 1992) using the 'typology matrix'. In certain project types, project managers must sustain the myth of organisational rationality through public performance of PM rituals (regular meetings and reporting, planning and problem solving) while at the same time engaging in backstage activity (wheeler-dealing, fixing and negotiating trade-offs, using managerial judgment and establishing a sense of ownership in directly affected stakeholders). These capabilities, Flyvbjerg (2001) argues, are best developed in the education process through a combination of practical theorising and individual ethical reflection on one's own significant concrete experience.

\section{Concluding remarks}

Project management courses are a common ingredient of business school curricula at all levels. There is a growing body of evidence of a steady and fruitful effort, especially since the formation of the 'Rethinking Project Management' Network (Winter et al, 2006), to elevate PM education beyond the perceived instrumental-technical nature of the field towards a theoretically informed, multidisciplinary and applied academic subject. The aim of our paper has been to conceptualise, justify and argue for the practice of responsible project management education (RPME) and discuss its implementation by reflecting on an example of a PM module at MBA level from our own practice.

Table 1 summarises the four proposed principles of RPME and the underpinning conceptual rationale. We suggest that it would be irresponsible not to transparently address the realities of ambiguous organising in a complex global world of projects and its socio-political drivers. The perceived nature of project management theory, and of the field as practised, requires continuous problematisation and questioning in light of practitioners' lived experience. Increasingly articulated general concerns around ethical management practices and the ethics of management education itself, need to be addressed collectively within academic and practitioners' PM communities and reflected in the practice of responsibly educating responsible project managers.

As outlined at the beginning of the paper, we have adopted a participatory pedagogic approach for PM education where 'relevance to practice' is a guiding principle, where 'PM practice' is understood as 
an action embedded in a specific context in the living present rather than a purely technical competence of following a set of universal instrumental rules and standards believed to be applicable everywhere at any time. We have developed and practised a pedagogy which encourages a deep engagement with the discursive construction of project environments, with the paradox of failing projects producing winners as well as losers, with the proliferation of PM qualifications and professional project managers. It promotes the theorising of the process of projectification, relational complexity and practical wisdom (combining instrumental and value rationality) and uses Turner and Cochrane's (adapted) project typology matrix as an inspirational introductory framework, making the theories and theorising accessible and appealing.

Challenging the conventional wisdom in the classroom can be a painful and daunting task but the students' feedback has shown that it is exactly through such a process that new possibilities for alternative action in the workplace emerge and are taken into consideration. We have provided and discussed some statements from the student feedback to get a feel of their lived experience with the module, categorizing them as: discomfort caused by encountering a different 'project management'; excitement in embracing the unexpected; and light-bulb moments in redefining their own understanding of PM practice and dealing with a specific situation in the workplace. This is an important aspect of evaluation of our largely theoretical argument. It requires a deeper, focused analysis in the future, given the institutional ambition of universities offering management education to be "rooted in the real world of business...", providing a "practical insight into the key issues facing organisations today" and delivering "applied business education and key methodologies relevant to the real world". [citation?]

It is important to observe that the presented argument for responsible PM education and for Turner and Cochrane's project typology matrix as a teaching framework is a product of our sense-making and interpretation. Interpretation is a powerful process. However, it is not value-free. Arguments outlined here reflect our own intellectual commitments and cultural and professional backgrounds, our own understanding and engagement with P\&PM in the workplace as both researchers and practitioners, and our own choices of theoretical positions from which ambiguity, complexity and realities of project-based work can be made sense of. The references to extant research and theoretical conceptualisations used in this paper are indicative rather than representative of the full scale of considered theoretical possibilities. This is our invitation to start a critical dialogue with fellow PM scholars in an attempt to, in a responsible way, make project management education relevant to all MBA course participants - current and future project practitioners, team members and senior decisionmakers alike. 


\section{References}

Brockbank A and McGill I (2007) Facilitating reflective learning in higher education Society for Research into Higher Education and Open University Press: Maidenhead.

Buchanan D and Boddy D (1992) The Expertise of the Change Agent: Public Performance and Backstage Activity Prentice Hall International: New York.

Buchanan D and Badham R (1999) Power, Politics, and Organisational Change: Winning the Turf Game SAGE: London

Cicmil S Gough G., and Hills S (2017) 'Insights into responsible education for sustainable development: the case of UWE, Bristol" International Journal of Management Education, (UN PRME's $10^{\text {th }}$ Anniversary Special Issue) 15(2), Part A (July).

Cicmil S Lindgren M and Packendorff J (2016) 'The project (management) discourse and its consequences: On vulnerability and un-sustainability in project-based work' New Technology, Work and Employment Vol. 31, No.1, March, pp.58-76.

Cicmil S, Williams T, Thomas J, and Hodgson D (2006).'Rethinking Project Management: Researching the Actuality of Projects' International Journal of Project Management, Vol 24, November, pp.675-686.

Cicmil S (2006) 'Understanding Project Management Practice Through Interpretative and Critical Research Perspectives' Project Management Journal, Vol. 37; Issue 2, June, pp.27-37.

Clegg S, Pitsis T, Marossheky M and Rura-Polley T (2006) 'Making the future perfect: constructing the Olympic dream' in Hodgson D and Cicmil S eds. Making Projects Critical, Palgrave McMillan: Basingstoke, UK and New York, USA, pp.265-293.

Cooke-Davies T, Cicmil S, Crawford L and Richardson K (2007) 'We're Not In Kansas Anymore, Toto: Mapping the strange landscape of complexity theory, and its relationship to project management' Project Management Journal - Research Quarterly, Vol. 38; Issue 2, June, 50-61.

Elliott C (2003) 'Representations of the Intellectual: Insights from Gramsci on Management Education' Management Learning, Vol. 34 (4), pp.411-427.

Fincham, R. (2002) 'Narratives of Success and Failure in Systems Development', British Journal of Management, 13, 1, pp.1-14.

Flyvbjerg B (2001) Making Social Science Matter: Why social inquiry fails and how it can succeed again (reprinted 2003) Cambridge University Press: Cambridge.

Flyvbjerg B (2014) 'What You Should Know About Megaprojects and Why: An Overview' Project Management Journal, Vol. 45, No. 2, pp.6-19.

Fowler N Lindahl M, Sköld D (2015) "The projectification of university research", International Journal of Managing Projects in Business, Vol. 8, Iss 1, pp.9-32.

Freire P. (2013[1974]). Education for Critical Consciousness edition by Bloomsbury Academic, London

Gaggiotti H, Simpson P and Cicmil C (2017) 'Re-imagining Business Schools of the Future as Places of Theorizing', in Michał Izak et al. (Eds): The Future of University Education, Palgrave: London. pp.207-225.

Geertz C. (1973) The Interpretation of Cultures. Basic Books: New York

Hibbert P. (2013) 'Approaching Reflexivity Through Reflection: Issues for Critical Management Education', Journal of Management Education, 37(6), pp.803-827.

Hodgson D. and Cicmil, S. (2016) Making Projects Critical 15 years on: A retrospective reflection (2001-2016). International Journal of Managing Projects in Business, 9 (4). pp.744-751.

Hodgson D, Lindgren M, Packendorff J and Cicmil S (2016) 'Introduction: The Politics of Projects in Technology- Intensive Work', Editorial, New Technology, Work and Employment Vol. 31, No.1, March, pp.1-3.

Holman D (2000) 'Contemporary models of Management Education in the UK' Management Learning, Vol. 31 (2), pp.197-217.

Izak M, Kostera M and Zawaszki M (2017) The Future of University Education (Palgrave Critical University Studies) Palgrave Macmillan: London. 
Konstantinou E and Müller, R (2016) 'Guest editorial for SI on the philosophy of project management' Project Management Journal, Jun/Jul2016, Vol. 47 Issue 3, pp.3-11.

Lannon J, Aherne D, Burke C (2016) 'Guest editorial for SI on project management in international development' International Journal of Managing Projects in Business Vol. 9 No. 3, pp. 546-561.

Laszlo E (1994) "The evolutionary project manager" in Cleland D I and Gareis R (1994) Global Project Management Handbook, McGraw - Hill International Editions, pp. 3-1 - 3-7.

Lindahl M. and A. Rehn (2007) 'Towards a Theory of Project Failure', International Journal of Management Concepts and Philosophy 2, 3, pp.246-254.

Lindgren M and J. Packendorff (2007) 'Performing Arts and the Art of Performing - On Coconstruction of Project work and Professional Identities in Theatres', International Journal of Project Management, 25, pp.354-364.

Linehan C, and Kavanagh D (2006) From project ontologies to communities of virtue, in Hodgson, D. and Cicmil, S. (eds) Making Projects Critical, Palgrave McMillan, Basingstoke and New York, pp.51-67.

Maylor H., T. Brady, T. Cooke-Davies and D. Hodgson (2006) 'From Projectification to Programmification', International Journal of Project Management, 24, 8, pp.663-674.

Painter-Morland M, Sabet E, Molthan-Hill P, Goworek H. and de Leeuw S. (2016) 'Beyond the Curriculum: Integrating Sustainability into Business Schools', Journal of Business Ethics, 139(4), pp.737-754.

Painter-Morland M. (2015) 'Philosophical assumptions undermining responsible management education', Journal of Management Development, 34(1), pp.61-75.

Paton S and Hodgson D (2016) Project managers on the edge: liminality and identity in the management of technical work New Technology, Work \& Employment. 31(1) pp.26-40.

Paton S, Chia R and Burt G (2013) Relevance or 'relevate? How university business schools can add value through reflexively learning from strategic partnerships with business' Management Learning 45(3), pp.267-288.

PRME (an initiative of the United Nations Global Compact) (2017a) History (online) http://www.unprme.org/about-prme/history/index.php last accessed April 2017.

PRME (an initiative of the United Nations Global Compact) (2017b) Principles (online) http://www.unprme.org/about-prme/the-six-principles.php last accessed April 2017.

Reed M and Anthony P (1992) 'Professionalizing management and managing professionalization: British management in the 1980s' Journal of Management Studies, 29:5, pp. 591-613

Rolfe, B, Segal, S and Cicmil S (2017) "The Wisdom of Conversations: Existential Hermeneutic Phenomenology (EHP) for Project Managers" International Journal of Project Management 35 (2017) pp.739-748.

Roth, K and Smith, Ch. (2009) 'Live Case Analysis: Pedagogical Problems And Prospects In Management Education' American Journal of Business Education 2(9), 59-66.

Smith C (2006) 'A tale of an evolving project: failed science or serial reinterpretation' in Hodgson D and Cicmil S eds. Making Projects Critical, Palgrave: Basingstoke, pp.265-293.

Stacey, R. \& Mowles, C (2016) Strategic Management and Organisational Dynamics: The challenge of complexity to ways of thinking about organisations; 7th ed. London: Pearson Education.

Solitander, N., Fougère, M., Sobczak, A. and Herlin, H. (2012) 'We Are the Champions: Organizational Learning and Change for Responsible Management Education', Journal of Management Education, 36(3), pp.337-363.

Steyaert, C, Beyes, T \& Parker, M (eds) (2016) The Routledge Companion to Reinventing Management Education. Routledge, Abingdon.

Turner J R and Cochrane R A (1993) "The goals and methods matrix: coping with projects for which the goals and /or methods of achieving them are ill-defined", International Journal of Project Management, 11 (2), pp.93-101.

Turner JR (1995) Editorial, International Journal of Project Management, 13 (6), p.351.

Van Der Hoorn B \& Whitty S (2015) A Heideggerian paradigm for project management: breaking free of the disciplinary matrix and its Cartersian ontology, International Journal of Project Management, 33(4), pp.721-734. 
Walker D and Lloyd-Walker B (2017) Rethinking project management: Its influence on papers published in the international journal of managing projects in business" International Journal of Managing Projects in Business, 9 (4) pp.716-743.

Winter M, Smith C, Morris P and Cicmil S (2006) 'Directions for Future Research in Project Management: The Main Findings of an EPSRC Research Network' International Journal of Project Management, Vol 24, November, pp.638-649 